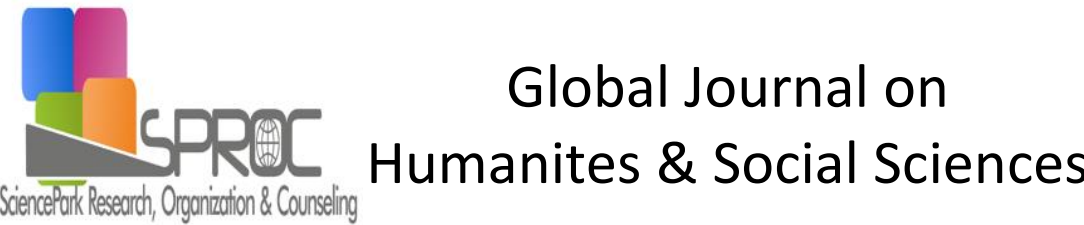

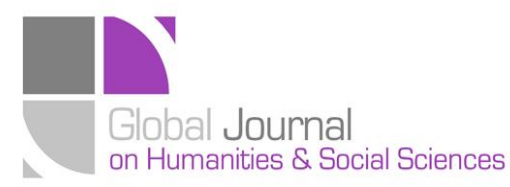

Vol 3 (2015) 207-215

Selected Paper of 4th World Conference on Design and Arts, (DAE-2015)

26-28 June 2015, St.Petersburg Christan University, St. Petersburg, Russia.

\section{Connecting Faith and Pedagogy: Fortune Favors the Brave}

Tiffany T. Boury*, Franciscan University, Steubenville, Ohio 43952, USA

Mary Kathryn McVey, Franciscan University, Steubenville, Ohio 43952, USA

\section{Suggested Citation:}

Boury, T. \& McVey, K. (2016). Connecting Fait and Pedagogy: Fortune Favors the Brave, [Online]. 03, pp 207-215. Available from:

http://sproc.org/ojs/index.php/pntsbs

Received January 18, 2015; revised March 17, 2015; accepted April 05, 2015.

Selection and peer review under responsibility of Prof. Dr. Milan Matijevic.

(C)2016 SciencePark Research, Organization \& Counseling. All rights reserved.

\begin{abstract}
This paper examines the defined charisms of an international field placement, the connection of those gifts with the culture and faith of participating preservice teaching candidates and investigates candidates' reflections of teaching persona and self-efficacy fostered by an international teaching experience. Launched in 2010, the ELISA (English Leaners in Specialized Atmosphere) program was intended to provide opportunities for preservice candidates to cultivate global classroom perspectives and culturally relevant teaching. As the partnership between the University and pilot schools in Gaming, Austria strengthened, the education faculty began to identify that something deeper was occurring. Participants in the field placements were not only developing pedagogy but connecting their faith to their reflective practice and teaching.
\end{abstract}

Keywords: Charism, Study Abroad, Preservice Teaching Candidates, Culturally Relevant Teaching

* ADDRESS FOR CORRESPONDENCE: Tiffany T. Boury, Franciscan University, Steubenville, Ohio 43952, USA. tboury@franciscan.edu 


\section{Introduction}

As America's educational institutions strive to encompass a more global perspective and foster career ready citizens, international partnerships that provide study abroad opportunities for preservice teacher candidates are in high demand. This article examines how the ELISA (English Learners in Specialized Atmosphere) program has not only provided opportunities for pre-service teacher candidates to develop their cultural competency but more importantly, the manifestation of connecting participant's perspectives of their faith to identified charisms.

Given the increasing demand of classroom diversity, it is important that educator preparation programs create global experiences that enable pre-service teachers' opportunities to become culturally competent in $21^{\text {st }}$ century schools. Romano and Cushner (2007) note international student teaching "can be the catalyst that starts teachers on a path of learning from others as well as forging relationships based on deep and meaningful understandings of people's similarities and differences" (p. 224). Myers (1996) predicts that by the year 2020, 46\% of students in the United States will be of color and Omoregie (2007) cites that the acquisition of global competencies is important because it allows the student to gain more than a local perspective of their cultural and pedagogical viewpoints. Kagan and Stewart (2005) note that the majority of graduates in educator preparation programs are white, female and accept jobs less than 200 miles away from their home communities; thus, contributing to the demand for pre-service candidates to have experience in diverse classroom settings.

When implemented, the mission of the ELISA program was to provide pre-service candidates an opportunity to work with English as a Second Language (ESL) students in Gaming and Schiebbs, Austria and advance relationships between Franciscan University's sister campus, the Kartause, and the Gaming community. Pre-service candidates were expected to post weekly reflections highlighting their experiences and connect those to their licensure area and the Ohio New Teacher Standards. In addition, pre-service candidates participated in four open dialog sessions throughout the semester using a WIKI or WikiWikiWeb (Brunsell \& Horejsi, 2010).

The use of WIKIS enabled users to contribute to a shared forum in hopes of fostering opportunities to build upon individual knowledge gained in the classroom and create a dialog focusing on observations and pedagogy. Through the use of a WIKI, pre-service candidates were not only defining the classroom pedagogy, they were observing and participating in ESL planning and instruction. As a Catholic institution, it was not surprising to read participants were writing about their faith; what became significant was a defined set of "gifts" or charisms the researcher's identified. The researchers propose that all Catholic educators from K-12 begin to define their own school's charisms and use these gifts to enhance curriculum and character education. The researchers offer that pre-service teachers who are taught to identify and purposefully incorporate charisms in their classroom will find greater confidence in the teaching and classroom planning.

\section{Charism Competency}

In 2005, U.S. bishops defined four pillars of Catholic education as "to provide an atmosphere in which the Gospel message is proclaimed, community in Christ is experienced, service to our sisters and brothers is the norm, and thanksgiving and worship of God is cultivated" (United States Conference of Catholic Bishops, 2005). As a Catholic institution, it became imperative that education faculty begin to examine their own pedagogical programs and identify how preservice candidates are experiencing and demonstrating the Bishop's call to effective Catholic education. Cook (2001) believes that Catholic education should exhibit an idiosyncratic and unified school culture rooted in the religious order the school is associated with. From this identified culture, each institution may begin to examine the special gifts of the Holy Spirit that their students, faculty and department mission use "to contribute to the common good and glorify God in the church and the world." (Cook, 2001). 
As a Franciscan sponsored institution, Franciscan University of Steubenville embraces the charisms of St. Francis. Govert (2010) identifies those truths as " the Franciscan charism includes the following dimensions: recognition of the primacy of Christ, reverence for all creation, respect for the dignity of the human person, community, peace-making, service, compassion, poverty , and simplicity" (p. 60).

\section{Impact of Religious Charism on Leadership and Identity}

Fitzgerald (2009) discusses the importance of leadership qualities defined in faith as "nuanced by the Gospel and often by the charism of a founding religious community" (p. 19). A charism is a spiritual gift given to serve the church and the needs of the world including a world vision and global responsibility.

McMahon (2011) believes that by defining the core values and integrating them throughout the curriculum helps to illustrate for students how the charisms define the values that will be guiding them throughout life (p. 20). According to Cook and Simonds (2002):

"building a culture of relationships, including relationship with self, God, others, the local and world community, and creation allows the students to develop a charism that is unique and meaningful to the contemporary Church and society " (p.319).

Cook and Simonds (2011) discuss a framework that provides one with a way to view relationships as "to bring people together in communion with one another" (p. 323).

\section{Purpose of the Study}

This longitudinal study's first purpose was to examine the collection of pedagogical and personal reflections of 64 participating preservice candidates in an international teaching field placement over four semesters. Participant's responses were collected via weekly reflections and WIKI postings. Researchers hypothesize that students' posts will support the charisms of service, relationships, teaching, and the dignity of each person.

Table 1. WIKI Discussions

WIKI Discussion Title Discussion Board Prompt

First Impressions

Home Culture

Challenges and Experiences

\author{
What are some initial impressions you have about your host culture? \\ How does this relate to your expectations about the culture before your \\ arrival? \\ After returning from your first field experience, reflect on some of the \\ ways the school was similar and different from your previous field \\ experience in the United States. \\ What have you done (or are doing) to introduce your pupils and others \\ to your "home culture"? \\ Are you teaching any content that relates specifically to the host \\ culture? If so, what? \\ What aspects of teaching in the host culture are proving most \\ challenging for you and how have you addressed those challenges? \\ How have you grown personally and professionally? \\ How are you going to apply what you have learned from teaching in \\ another culture in your practice? Is your global awareness broadened?
}

Adapted from the (COST) Consortium for Overseas Student Teaching handbook 


\section{Participants}

Participants of the initial study were 61 females and 3 male education majors at Franciscan University of Steubenville, Ohio. This international teaching experience occurred during the 2011-2013 academic years with pre-service candidates placed in the elementary, middle and vocational schools of Gaming, Austria. Due to transportation and scheduling issues, participants taught in the same classroom for the 14 week semester. Additionally each semester, 6 elementary licensure candidates were approved by the Austrian government to tour the community kindergarten in a day visit. In the vocational school, pre-service candidates participated in co-teaching scenarios with other pre-service candidates. In each of the school placements, pre-service candidates were expected to plan, teach and assist mentor teachers in weekly English lessons that were part of the Gaming curriculum.

\section{Data Collection}

Given the nature of the study, the researchers used a qualitative research model focused on the importance of the data (description) from the student participants. The design for this study is based on Participatory Action Research (Lewin, 1946). Lewin devised a series of steps implemented in group discussions or "think tanks" using the processes model of planning, acting, observing and reflecting.

Data for the research was collected through qualitative measures using weekly reflections based on the Ohio New Teacher Standards and WIKI discussion board prompts. In qualitative research, Creswell and Miller (2000) describe the metaphorical use of a "lens" to filter data; believing that a qualitative researcher's lens is not based on scores, instruments, or research designs. The lens is used to capture views of people who conduct, participate in, or read and review a study. Each WIKI discussion was aligned to follow the progression of cultural competence in the Developmental Intercultural Sensitivity Model (DMIS). Discussions boards “ addressed the ethnocentric stages of the continuum which preservice candidates may be experiencing. The third discussion board " probed candidates to look at the ethnorelative stage. Reflections used in this research paper are from WIKI postings submitted by the preservice candidates from the four semesters.

The data used in this study was nalysed using Carmen and Dooley's (2006) Text Analysis System 1.2 from Crawdad Technologies LLC. A total of 456 individual reflections were coded in an effort to identify common themes. These themes were then used to identify the culture of preservice candidates, their connection to their faith and how collectively these views describe the charism of Franciscan University's international field placement.

\section{The Charism of Relationships}

Given the increasing demands in $21^{\text {st }}$ century classrooms, to choose teaching as a career is to embrace a vocation which strives to enrich and nurture the personal best of each student. In the ELISA program, the first charism is and how those relationships connect to the pre-service candidates' global perspectives. Roose (2001) believes teachers who choose to study abroad reflect a greater ability to take risks in the classroom, they understand the importance of culture and how it relates to community, personal relationships and they demonstrate a better sense of classroom discipline, interactions and a shared respect with faculty, students and their families. 
Boury, T. \& McVey, K. (2016). Connecting Fait and Pedagogy: Fortune Favors the Brave, [Online]. 03, pp 207- 
Schmitt (2013) believes that educators must find the ability to articulate their faith and put this into practice. By identifying as a charism, the researchers challenge participants to self-reflect on their teaching in the Gaming classrooms. With a new perspective focused on the charism of teaching, the ELISA program began to investigate the Austrian school's curriculum and pre-service candidate's perspectives of how they may further incorporate and live their faith in their teaching.

\section{The Charism of Dignity of Each Person}

The final charism identified within the ELISA program focuses on researchers discern that this charism is fostered by the hospitality and kindness that the Austrian school faculty demonstrates to students, peers and the candidates. Barnes and Kohler-Evans (2013) summarize the importance of dignity as:

"Through relationships that we create with the students, various avenues open and honest conversations emerge about the student's needs, struggles, successes, and triumphs. It also allows for faculty members and students to strategize together how best to bolster the successes and address challenges (para. 7)."

The final charism of ELISA is

. This charism challenges pre-service teachers to accept each student at his or her academic, social and emotional level; thus appreciating each student's unique talents and contributions to the classroom.

\section{Discussion}

The researchers believe that participants of the ELISA program are using the charisms of and to self-discover their own charism and teaching persona. Pre-service candidates who participate in the international program gained the confidence to choose jobs where they would be more likely to find themselves as the minority within the majority and demonstrated greater self-efficacy in their field placements upon returning to the United States. In their final semesters at the university, three participants from the program committed to teaching positions in India, Africa and inner city Chicago citing that Gaming was the catalyst for this. And as a whole, education faculty note that pre-service candidates who complete the ELISA program are more likely to take risks and assert themselves in the classroom when compared to peers who elected to forgo the study abroad program.

This observation lead to the researchers second phase of the longitudinal study. In spring 2015, eighteen preservice teachers, 1 male and seventeen females, were required to read the initial paper 


\section{focused on the charism of the ELISA program entitled} framework to self-reflect on how they defined their own teaching charism after working in the Austrian schools. A majority of the pre-service candidates believed that the experience of being a minority fostered leadership and self-efficacy at a level they would not have experienced in their mother country. Further, pre-service candidates remarked they had not thought about their spiritual gifts or charism until they were required to write a purposeful reflection; however, they also felt a sense of power after defining and articulating how they had used their charism throughout the semester.

Table 2. Charism Reflections

I was not aware of this charism before teaching abroad. I have always been a follower. I never thought that I could be a good leader or that I had the charism to take charge in certain situations. I think what made this come about was me applying myself and mustering up the courage to lead the group discussion. I think it actually helped ease me into teaching with the fact that I did not know the students and that they were foreign. This is because they were mainly interested about where I came from, and were looking for help on how to improve their English. Talking about my home is enjoyable and comes naturally to me, and it was really neat to experience teaching my own language. I really see the Faschule fostering charisms. The teachers are always reminding the students of their classroom manners, and they push them to apply themselves by only speaking English while we were there

Yes, I think I was aware of it but here in Austria it became even stronger. My first early experience teacher was big on being confident in front of the students always. I learned this importance of this for her but always had room to grow. This semester I think that growth was fostered because it was sort of a sink or swim situation. My teacher just threw me into it. This was awesome because I learned a lot even through my own mistakes. There were days that I would go home and have to evaluate myself to see what I could do better next week. It did get easier as time went on and that again made me grow in this charism. I prefer, I had to use my charism of confidence and teach the children what she gave me. This taught me to think on my feet and to remain calm, and reaffirmed the importance of being a strong confident teacher. -

After the time I have spent in Austria, I have been able to look back on all the experiences I've had in the last few months, and am able to see that possess the charism of teaching. This is not just from the education standpoint, but also from a wider look into areas of relationships and the spiritual. I have been able to see that I have developed the desire to help those who come to me, whether with advice or school work. This has fostered my teaching experience because I have been able to try to focus more on individual students needs within the larger context of the lesson. I have also developed more listening skills, both in conversation and when it comes to criticism.

Teachers and schools should be aware of their own charisms as well as those of their students because not everyone is good at exactly the same things. Once teachers are aware of this, and are more aware of their students' charisms, the learning environment in the classroom will work much better and the relationships between students and teachers will be better. After reading the review, I understand more concretely how charism can really help the classroom and it makes me want to give charisms a role in my future classrooms. -

The ELISA program has allowed me to encounter and improve the relationship of self, God, and worldwide communities. But while I was building these relationships, I was openly expressing my beliefs and professing the truth of the Catholic Faith. If I teach at a public school, this proclamation charism that I possess will impact the students to view me as a leader without them realizing what aspects garner this respect. By demonstrating core cultural values through example rather than proclamation will become highly important. I hope to make a significant impact on the over sexualized and secular society in which we are living in, and this quote has inspired me to go out into this secular world and be the "light which shines in the darkness".-

Course Reflections. EDU 211, Blackboard. May 14, 2015 


\section{Challenges and Future Research}

Given the term charism and the university participants are of the Catholic faith, the researchers acknowledge that the study is limited to the Christian religion; however, the researchers' intent is to start a dialog with other institutions of faith.

Second, the researchers propose that the study of faith and pedagogy may contribute to the curriculum of Social and Emotional learning by (1) further enhancing faculty professional development, (2) modeling a school culture that respects and appreciates diversity and (3) provides the tools needed for new teachers to successfully build a positive and productive classroom culture.

Finally, using their program findings on the power of charisms and teacher efficacy, the researchers are looking for other teacher preparation programs who desire to begin planning professional development workshops which enable school communities to define individual teaching charisms and use those results to create purposeful school mission statements and goals.

\section{References}

Barnes C. \& P. Kohler-Evans (2013, July) Remembering our mission to teach.

Retrieved from: http://www.facultyfocus.com/articles/philosophy-of-teaching/remembering-our-mission-to-teach/

Bennett, M. J. (2004). Becoming interculturally competent. In J. Wurzel (Ed.), (pp. 62-77). Newton, MA: Intercultural Resource Corporation.

Brennan, S. and Cleary, J. (2007) Promoting reflection during overseas student-teaching experiences: One university's story. In K. Cushner, \& S. Brennan (Eds.),

(pp. 159-177). Lanham, MD: Rowman \& Littlefield Education

Brunsell, E., \& Horejsi, M. (2010). Wiki, wiki! (4), 12.

Cook, T.J. (2001).

Washington, D.C: National Catholic Education Association.

Cook, T.J. (2004). Charism:

Momentum, February/March, 2004. 18-21.

Corman, S. and Dooley, K. (2006),

. Chandler, AZ: Crawdad Technologies, LLC.

Creswell, J. (2005). Educational research: planning, conducting, and evaluating quantitative and qualitative research (p.551-557). Upper Saddle River: Pearson

Creswell, J. W., \& Miller, D. L. (2000). Determining validity in qualitative inquiry. 130.

Cummings, J.L. (2004). Is there a lay charism for today's catholic school?, Momentum, February/March, 2004, 24-25.

Fitzgerald, M. (2009). Educational leadership and the impact of religious charism, Momentum, February/March, 2009, 18-22.

Govert, M.E. (2010). One university's attempt to name the Franciscan charism in higher education

Grant, C. A. (1992).

(1), 59-72.

Palmer Press

. Bristol, PA:

$$
\text { . (2011). Mich.: Zondervan. }
$$

McMahon, R. (2011). Defining core values leads to a new charism, Momentum, February/March, 2011, 18-21

Mears, K. (2013). Do you teach students or subjects? the subject of education must be the student! Retrieved from:

Myers, E. (1996). A culturally diverse field experience setting for preservice teachers. 286-289

Omoregie, N. (2007). The globally competent teacher in secondary level education.

(1), 3-9

Pope Benedict (2008). Evangelization is the mission of the church.

Retrieved from http://www.christlife.org/resources/articles/popequote.html 
Romano, R., \& Cushner, K. (2007). Reflections on the importance and value of the overseas student-teaching experience In K. Cushner, \& S. Brennan (Eds.),

(pp. 215-225). Lanham, MD: Rowman \& Littlefield Education

Roose, D. (2001), White teachers' learning about diversity and "Otherness": The effects of undergraduate international internships on subsequent teaching practices. 43-49.

Schuttloffel, M. (2012). Catholic identity, the heart of catholic education.

148-154

Schmitt, K. (2013), Why religious education assessments are important in the new evangelization and the year of faith: an explanation of religious assessments and their benefits. Retrieved from http://www.ncea.org/sites/default/files/documents/ifg acre Why RE Assessments Are Important 2 0130207.docx

Stewart, V., \& Kagan, S. (2005). Conclusion a new world view: Education in a global era. 241-245.

United States Conference of Catholic Bishops. (2005).

. Washington, D.C.:Author

Wagner, D. (2001) Like a northbound train: a vision of catholic education.

Zera-Laughlin, D.A. (2004). Incarnating charism into a school's way of life., Momentum, February/March, 2004, 23-24. 